Article

\title{
Environmental Governance at an Asymmetric Border, the Case of the U.S.-Mexico Border Region
}

\author{
Gabriela Munoz-Melendez ${ }^{1, *(D)}$ and Sarah E. Martinez-Pellegrini ${ }^{2}$ (D) \\ 1 Department of Environmental and Urban Studies, El Colegio de la Frontera Norte, Tijuana 22560, Mexico \\ 2 Department of Public Administration Studies, El Colegio de la Frontera Norte, Tijuana 22560, Mexico; \\ sarahm@colef.mx \\ * Correspondence: gmunoz@colef.mx; Tel.: +52-664-631-6300 (ext. 1312)
}

Citation: Munoz-Melendez, G.;

Martinez-Pellegrini, S.E.

Environmental Governance at an

Asymmetric Border, the Case of the

U.S.-Mexico Border Region.

Sustainability 2022, 14, 1712.

https://doi.org/10.3390/su14031712

Academic Editor: Luigi Aldieri

Received: 1 December 2021

Accepted: 13 January 2022

Published: 1 February 2022

Publisher's Note: MDPI stays neutral with regard to jurisdictional claims in published maps and institutional affiliations.

Copyright: () 2022 by the authors Licensee MDPI, Basel, Switzerland. This article is an open access article distributed under the terms and conditions of the Creative Commons Attribution (CC BY) license (https:// creativecommons.org/licenses/by/ $4.0 /)$.

\begin{abstract}
Environmental issues at the U.S.-Mexico border have been approached in a fragmented way and considered of minor political interest; even though they have been addressed in treaties and agreements, regional environmental pollution persists. One may ask what sort of measures should be taken to address the complex and long-term environmental problems in the U.S.-Mexico border region. To answer this question, an environmental cross-border governance proposal was evaluated by applying Qualitative Analysis of Textual Data to the text of Chapter 24 of the USMCA treaty. The results indicated that the environmental policies concerning the border region still lack a coherent systemic approach, and hence will lead to inefficiency. Territorial development is heavily dependent on national environmental governance and priorities; however, environmental issues should be understood in an integral, complex and deeply entangled way if they are to be effectively addressed. Otherwise, environmental degradation is likely to expand due to population growth and events associated with climate change.
\end{abstract}

Keywords: U.S.-Mexico border region; complexity; transboundary governance; long-term sustainability

\section{Introduction}

Talking about governance means describing a complex set of institutions which shape broad social agreements according to a specific system that may be understood as a socially constructed space. These institutions include organizations and rules, both formal and informal, through which priorities, responsibilities, limits for agents' actions and costs as well as benefits are allotted. Assuming that the governance model in a given region determines how policies are designed and implemented, in this paper we assume that good governance is related to effective action concerning public problems. Thus, we propose five principles for good governance: (1) public and private participation; (2) openness regarding information access and transparency; (3) shared responsibility among different levels and actors; (4) effectiveness; and (5) coherence and coordination among various policies. These principles are based on subsidiarity and proportionality.

No initiative is to be undertaken unless: (a) public intervention proves to be necessary; (b) the government steps in at the appropriate level; and (c) the scope of the mediation is proportional to its aims [1]. Another important fact to consider is that organizations and rules may achieve different levels of development in the same territory, and thus challenge the opportunity to achieve policy goals or generally accepted objectives. Regarding transboundary regions or territories, differences in the rates of evolution of various institutions might be enhanced by national bias.

The meanings and manifestations of "environmental governance" are numerous, possibly because of dynamic systems as well as the multiple interests, actors and scales involved. Moreover, because of interactions among these elements, environmental governance affects all scales of leadership, namely global, state and substate levels [2], and includes actors 
from the public and private sectors on different territorial levels, which may interact in a dynamic and changing way, and not necessarily in a hierarchical manner.

Despite discrepancies resulting from diverse and even opposing standpoints regarding the analysis and interpretation of the various forms of environmental governance, such analyses must take into account complex and serious problems [3], as well as challenges related to addressing structural problems characterized by substantial time delays between policy enforcement and evidence of its effects [4]. It must be acknowledged that research on complexity has recently gained prominence in environmental sustainability science with regard to the political conditions required to solve complex problems [2], such as nonpoint source (NPS) water pollution [5] and climate change [6]. Even some of the proposals developed by public choice economists could be considered relevant in discussions of environmental governance when approaching the decision-making processes involved.

However, given the transboundary nature of some environmental problems, such as droughts, desertification, acid rain, air pollution, etc., international, national and subnational institutions are not necessarily able to implement measures on an appropriate scale [7] for policy interventions. None of these scales are sufficient to devise an appropriate analytical approach to describe scenarios or, moreover, to step in when countries have decentralized natural resource management systems, to enhance community-level participation, transparency and accountability. Additionally, there is often a problem of insufficient funds to carry out functions [8].

Environmental regional governance was developed to address significant gaps in transboundary issues surpassing national borders; this type of governance is understood as a group of initiatives with which to generate transgovernmental networks and partnerships between public and private actors to achieve effective policies addressing complex social problems, including those related to sustainability. The two main instruments of regional environmental governance are agreements and organizations. Studies on environmental regional governance around the world have revealed that there is not a single approach to regional cooperation and governance [9] because regions have their own specific organizational structures, governance networks following local priorities and formal/informal institutions.

Scenarios taking place at national borders are of particular interest to environmental regional governance to the extent that a specific form of governance is applied, "crossborder governance", given its methodological approach designed to describe horizontal policy coordination across sectors and agents, as well as vertical policy coordination across different levels of government, even under institutional asymmetries. This type of governance can capture and characterize working interactions regarding cross-border and transboundary environmental issues in regions that belong to different nations, issues that clearly cannot be resolved by policy actions at the national or subnational levels. The performance of this kind of governance may be assessed by examining whether cross-border cooperation among different actors leads to sustainable transboundary development.

A great deal of research has been done on cross-border environmental governance in Europe [10], on issues such as environmental legislation [11-14], water resources [15,16], biodiversity protection [17], climate change [18,19] and renewable energy [20]. Furthermore, the performance of the European model has been compared with that of North America [21,22] and MERCOSUR [23]. In Asia, studies have focused on the environmental challenges among the ten countries comprising the Southeast region [24-26], as well as on cross-border water resources [27-30] and biodiversity conservation [31] in China, crossborder environmental pollution in Hong Kong [32] and water resource management in Australia [33]. Studies have also covered collaborations [34], biodiversity conservation [35] and water resource management [36] in East Africa in addition to land systems [37] and conservation [38] in Latin America.

Investigations on cross-border environmental governance have been extensively carried out in North America due to conditions brought about by the 1994 North American Trade Agreement (NAFTA); this project was constructed around economic interdepen- 
dencies as well as structural complementarities between Mexico, Canada and the U.S. despite the large political, social and economic asymmetries between the poor (Mexico) and wealthy (U.S. and Canada) member states. The latter have a long tradition of working together on shared transboundary issues even prior to NAFTA [39] and continued their effective environmental partnership during NAFTA. In contrast, the U.S. and Mexico were unable to develop a comprehensive strategic plan for environmental protection along the border during the time that NAFTA was enforced; their border has been considered an example of a paradox of persisting borders in a globalizing world [40]. On 1 July 2020, NAFTA was substituted by the United States-Mexico-Canada Agreement (USMCA). Will this create better conditions for cross-border environmental governance at the U.S.-Mexico border region?

This paper focuses on analyzing the complex environmental processes taking place at the asymmetric border between the U.S. and Mexico. To achieve this goal, the current environmental governance model was evaluated against the criteria of Wong Villanueva's model [41] while trying to address the following questions:

- How good is the current environmental cross-border governance at the U.S.-Mexico border region?

- What sort of measures should be taken to address complex and long-term environmental problems in U.S.-Mexico cross-border governance?

\section{Materials and Methods}

The present border between the U.S. and Mexico is the result of the Guadalupe Hidalgo (1848) and Gadsden (1835) treaties. Prior to this, the American Southwest was first a Spanish colony and then part of Mexico. Between 1836 and 1853 the U.S. acquired these territories from Mexico because of the Texas Revolution (1836), the U.S.-Mexico War (1845) and the Gadsden (la Mesilla) purchase (1853) [42]. The 1970 Boundary Treaty resolved all pending boundary differences and maintained the Rio Grande and Colorado River as the international boundaries.

The U.S. and Mexico share a $3145 \mathrm{~km}$ (1954 m) border, excluding the maritime boundaries of $29 \mathrm{~km}(18 \mathrm{~m})$ in the Pacific Ocean and $19.3 \mathrm{~km}(12 \mathrm{~m})$ in the Gulf of Mexico. The border region is an area that is $200 \mathrm{~km}(124 \mathrm{~m})$ wide, with $100 \mathrm{~km}(62.5 \mathrm{~m})$ on either side of the international boundary. This area was declared an official borderland by Article 4 of the $1983 \mathrm{La}$ Paz Agreement. The border region is comprised of 25 counties in the American states of California, Arizona, New Mexico and Texas in addition to 35 municipalities in the Mexican states of Baja California, Sonora, Chihuahua, Nuevo Leon, Coahuila and Tamaulipas (see Figure 1). According to 2019 U.S. Census Bureau data, 7.5 million people live in the U.S.-Mexico border region.

Oscar Martinez [43] tried to explain the complex interactions of the U.S.-Mexico border region by suggesting four models. First, the alienated borderlands-the result of hostility between nations when there is not cross-border interaction. Second, the coexistent borderland, with a minimum of cross-border contact. The third model refers to the interdependent border region, when linked border communities lead to the emergence of economic exchange and human movement across the border. The last model refers to integration under a borderless and barrier-free scheme.

Francisco Lara studied the San Diego, California-Tijuana, Baja California border region and reported that transborder cooperation could adopt three distinctive modalities [44]. These are in an ascending order of formality: convergence, collaboration and co-management. Convergence describes a spontaneous cooperation, usually related to the existence of shared problems and goals. Collaboration refers to a limited and flexible cooperation mechanism, while co-management implies cooperation in institutional, human and financial dimensions. Sergio Peña added a fourth modality, the highest form of transnational governance: integration [45]. This author also graphically presented the statements of Martinez and Lara, adding the work of Ostrom on institutions [46] that operate under three types of rules: operational, collective and constitutional. 


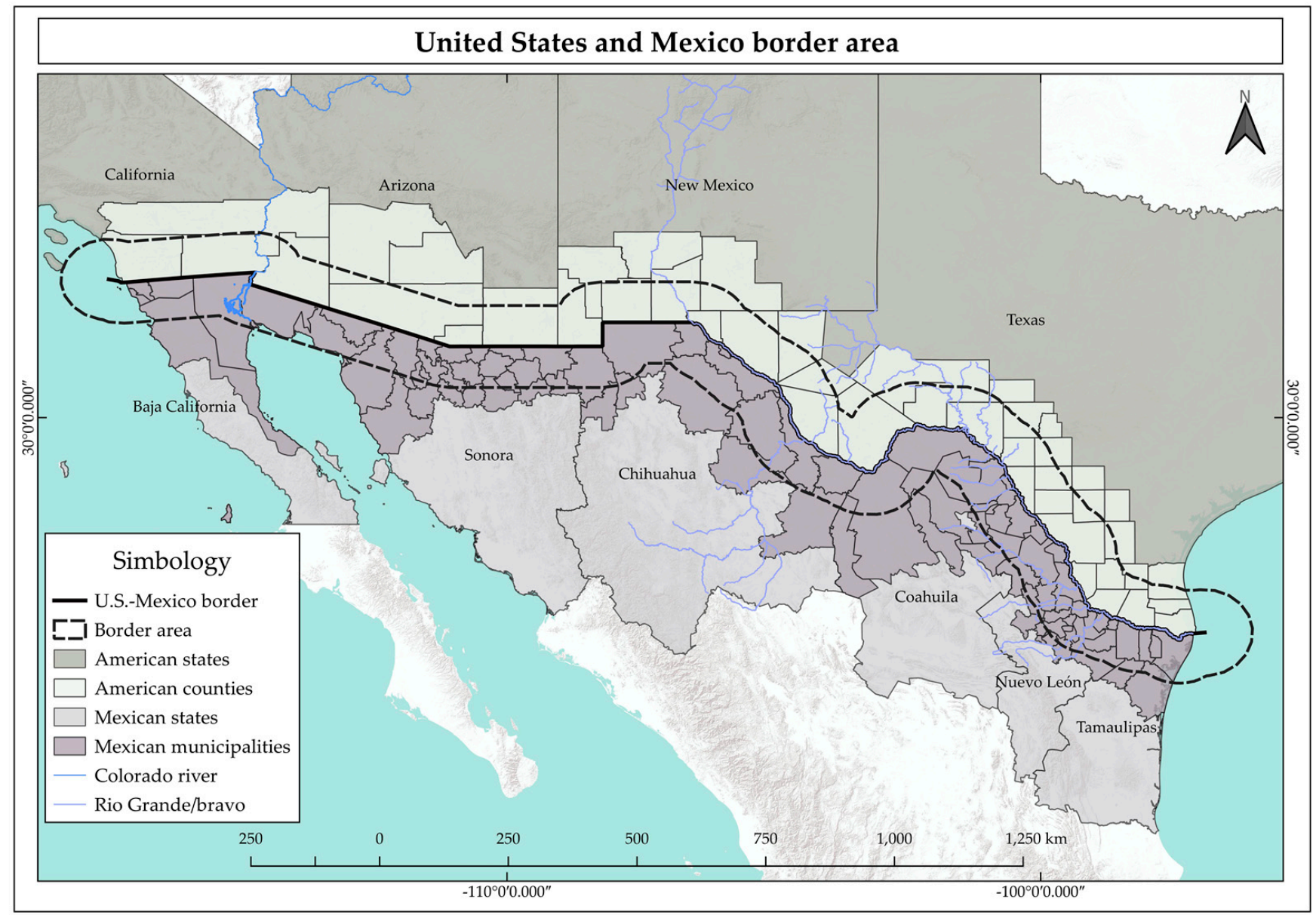

Figure 1. The U.S.-Mexico border area. Source: created by authors.

The origins of border environmental cooperation between Mexico and the U.S. can be traced back to 1884, when the International Boundary and Water Commission (IBWC) was created to deal with issues regarding the binational rivers that served as a border demarcation. Multiple conflicts over the water distribution of both rivers took place in 1885, 1892, 1902, 1905 and 1906, with an interruption of negotiations of eight years. After nearly 30 years, binational talks resulted in the International Water Treaty of 1944 . It established the legitimate and equal access to shared natural resources separated by an international border, declared that no state shall claim or exercise sovereignty rights over shared resources and assigned the responsibility of nation states to rationally use and preserve shared water resources.

The 1944 International Water Treaty granted further responsibilities to the IBWC, such as jurisdiction over surface and groundwater, water sanitation and quality in addition to border-crossing projects. However, the IBWC did not impact the planning and administration of international waters, and by the 1960s its functions were visibly insufficient to deal with cumulative environmental impacts caused by four events.

The first event was the Bracero program (1942-1964), which gave temporary agricultural and railroad construction jobs to Mexican workers in the U.S. to address the American labor shortage caused by the Second World War. At the end of the Bracero program, two other programs replaced it: the National Border Program (Programa Nacional Fronterizo) (1961-1965) and the Border Industrialization Program. The first aimed to attract American tourism to the Mexican side and promote Mexican products in America, and constituted the second event that had an environmental impact on the border region. The Border Industrialization Program, the third event, promoted the assembly industry (maquiladora) scheme in Mexico (1964—current date) and increased internal migration. The fourth event 
was the internal migration in the U.S. after the Second World War (Sun Belt migration), which caused significant population growth in the border region [47].

The direct result of this population growth and increase in industrial activities at the border region was generalized environmental degradation in urban and rural settings alike, caused by the lack of infrastructure with which to deal with water treatment and waste disposal. On the Mexican side, in addition, environmental problems resulted from the lack of urban planning and limited as well as uncertain federal funds [48]. By the 1980s, the situation was such that Mexico and the U.S. began several bilateral programs to deal with the border environmental problems and initiated bilateral debates that ended with the draft of the La Paz Agreement in 1983, to address problems of air, land and water pollution in the border area and to define the width of the U.S.-Mexico border region.

The La Paz Agreement was the first tool to deal with environmental conflicts between two nations and was considered visionary for its time. Of relevance were the public participation and policy decentralization in executing the agreement [49]. However, it failed to address numerous environmental issues in the border area, such as the lack of investment in pollution abatement and remedial measures [50], partially because of the low priority the governments conferred to the agreement.

In 1994 NAFTA came into effect, creating one of the largest free-trade zones in the world. This project was constructed around economic interdependencies between Mexico, Canada and the U.S. to increase trade flows. Under NAFTA integration was limited, keeping borders and enhancing industrial production under structural complementarities. Environmentalists took the opportunity to mend the La Paz Agreement's failures, forcing negotiators to include "non-trade issues" such as labor and environmental matters in its parallel agreements; in doing so, NAFTA became the first significant trade agreement to include environmental clauses.

The side agreement NAAEC focused on the specific action of environmental violations affecting the core trade agreement. It mandated the creation of the Commission for Environmental Cooperation (CEC), supervised by a joint public advisory committee. In addition, NAFTA created the North American Development Bank (NADBank) and the Border Environment Cooperation Commission (BECC); these worked together with communities and project sponsors to develop, finance and build affordable and self-sustaining environmental infrastructure projects. This institutional framework was designed under American standards and demanded strict technical and financial requirements for project proposals - these presented a problem to Mexican border communities and municipalities that were unable to reach those requirements.

NAFTA modified the institutional context at the U.S.-Mexico border region, adding actors and organizations to the already existing ones at the national and subnational levels. Additionally, it is credited as having allowed Mexico to avoid turning into a pollution haven, creating investment in infrastructure-mostly in the water sector-improving the life of many border residents, building a stable binational relationship, controlling pollution in the long term [51] and encouraging coalition-building among NGOs [52].

However, improvements seem to be the exception rather than the norm [53]. NAFTA did not consider dispositions for the follow-up of on-going political processes. In addition, the institutions created to attend the regional environment-BECC and NADBank-proved to have a limited and opaque performance, drawing attention to the need to update their objectives, functions and capabilities [54]. Yet, after 25 years, the U.S. and Mexico were unable to develop a comprehensive strategic plan for environmental protection along the border; the criticisms that were directed to the La Paz Agreement in the mid-1980s and early 1990s endured [55].

On 30 September 2018 the USMCA was drafted with the intention of replacing NAFTA; it was signed on 30 November 2018, and a revised version was endorsed on 10 December 2019. The USMCA came into effect on 1 July 2020. Its Chapter 24 is envisioned as the most advanced and comprehensive chapter on the environment of any trade agreement and could be considered as a support for sustainability because seven multilateral environ- 
mental agreements are included in the text, although treaties dealing with binding climate standards and commitments, such as the Paris Agreement, are ignored. Only carbon storage is mentioned in the sustainable forest management section and clean technology in a non-binding section on environmental good [56].

To evaluate the recent environmental cross-border governance brought by the USMCA at the U.S.-Mexico border region, the theoretical framework model of Wong Villanueva et al. [41] was applied. In particular, how well the new model complied with the ten criteria considered to drive "good" cross-border governance (CBG), see Table 1.

Table 1. The cross-border governance evaluation criteria.

\begin{tabular}{|c|c|c|}
\hline Criteria & Description & Representative Keywords \\
\hline $\begin{array}{l}\text { Common agenda and national } \\
\text { sovereignty }\end{array}$ & $\begin{array}{c}\text { A common cross-border integration } \\
\text { agenda respecting the principle of } \\
\text { national sovereignty }\end{array}$ & purpose, objectives, goals, priorities \\
\hline Stable organizational structure & $\begin{array}{c}\text { Institutional and legal framework in each } \\
\text { country involving inter- and } \\
\text { intra-sectorial structures and their } \\
\text { evolution, ensuring functionality }\end{array}$ & $\begin{array}{l}\text { local, regional, international, legal, } \\
\text { institutional, structures, inter }\end{array}$ \\
\hline Multi-level model & $\begin{array}{l}\text { An agreed governance level and } \\
\text { recognition of key actors with a } \\
\text { clear relations framework }\end{array}$ & rules, procedures \\
\hline Institutional mix and articulations & $\begin{array}{l}\text { Enhancement of institutional variety } \\
\text { Articulation of formal and informal } \\
\text { stakeholders and mechanisms }\end{array}$ & stakeholders \\
\hline Bonding links & $\begin{array}{l}\text { Strengthening of network relations in } \\
\text { formal ways and links }\end{array}$ & mutual, relations \\
\hline Internal and externalcommunication & $\begin{array}{c}\text { Effective channels for internal } \\
\text { communication and external } \\
\text { visualization }\end{array}$ & communication \\
\hline Growth potentials & $\begin{array}{l}\text { Identification of growth potentials } \\
\text { (development levers) } \\
\text { Understand the interaction of growth } \\
\text { potential with territorial processes } \\
\text { Sufficient resources and capacities for } \\
\text { executing plans }\end{array}$ & potential, development, growth, process \\
\hline Key actors, resources and goals & $\begin{array}{c}\text { Identification of key actors in priority } \\
\text { issues }\end{array}$ & factors, resources, sectors, issues \\
\hline Goal setting and planning & $\begin{array}{l}\text { Clear roadmap with long-term, } \\
\text { medium-term and short-term planning }\end{array}$ & risk, management \\
\hline Accountability & $\begin{array}{c}\text { Ensure transparency, access to } \\
\text { information and awareness vertically and } \\
\text { horizontally }\end{array}$ & regulation, review, decision \\
\hline
\end{tabular}

Source: Modified by authors from [41].

The text of Chapter 24, "Environment", of the USMCA treaty was used as data, using the r package quanteda: Qualitative Analysis of Textual Data [56], version 3.1.0 in RStudio 2021.09.0 "Ghost Orchid" release for macOS. Common English words such as the, at, on and etc. were removed; the remaining text was analyzed to count the occurrence and relationship among the representative keywords criteria listed in the third column of Table 1 . The qualitative textual analysis was also applied to the NAAEC text.

\section{Results and Discussion}

Figure 2 depicts the 15 most frequent words in Chapter 24, "Environment", of the USMCA. Figure 3 illustrates the network formed by relationships among the top 30 words. 
Table 2 presents the frequency of the occurrence of representative keywords of the CBG criteria. Figure 4 shows the comparison of the qualitative textual results between NAAEC and the USMCA.

As seen in Figure 2, "parties", "party" and "shall" are the most frequent words in the text of Chapter 24; these words are closely related, as depicted in Figure 3. Both figures denote the responsibilities and compromises of state members on actions that certainly will or must happen according to the USMCA agreement. These three words are generic terms depicting a broad concept of the current and future agenda, the organizational structure, resources and key actors. It is possible to observe that the multi-level model recognizes the leadership of national regulations and thus rules against the establishment of monitoring institutions such as the CEC.

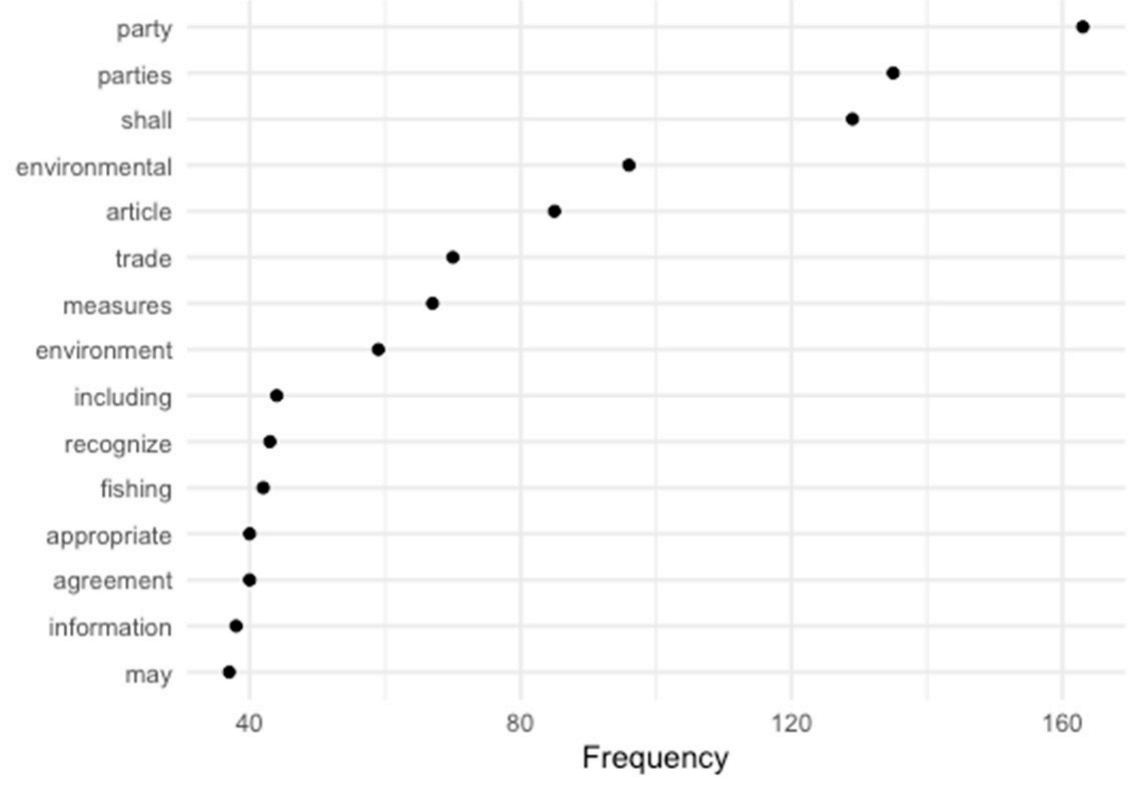

Figure 2. The 15 most frequent words in Chapter 24, "Environment". Source: elaborated by authors.



Figure 3. Word cloud of the relationship among the 30 most common words in Chapter 24, "Environment". Source: elaborated by authors. 
Table 2. Times that the CBG criteria are addressed in function of the occurrence of representative keywords in Chapter 24 of the USMCA treaty.

\begin{tabular}{ccc}
\hline CBG Criteria & $\begin{array}{c}\text { Number of Times } \\
\text { Criteria Is Addressed }\end{array}$ & Representative Keywords (Mentions) \\
\hline $\begin{array}{c}\text { Common agenda and } \\
\text { nationalsovereignty }\end{array}$ & 22 & purpose (5), objectives (10), goals (2), priorities (5) \\
\hline $\begin{array}{c}\text { Stable organizational structure } \\
\text { Multi-level model }\end{array}$ & 38 & $\begin{array}{c}\text { local (2), regional (8), international (18), legal (6), } \\
\text { institutional (3), structures (1), inter (1) }\end{array}$ \\
\hline Institutional mix and articulations & 9 & rules (3), procedures (6) \\
\hline Bonding links & 1 & stakeholders \\
\hline $\begin{array}{c}\text { Internal and external } \\
\text { communication }\end{array}$ & 9 & mutual (8), relations (1) \\
\hline Growth potentials & 2 & commication \\
\hline Key actors, resources and goals & 25 & factors (1), resources (26), sectors (2), issues (7) \\
\hline Goal setting and planning & 26 & risk (2), management (26) \\
\hline Accountability & 28 & regulation (10), review (5), decision (1)
\end{tabular}

Source: elaborated by authors.

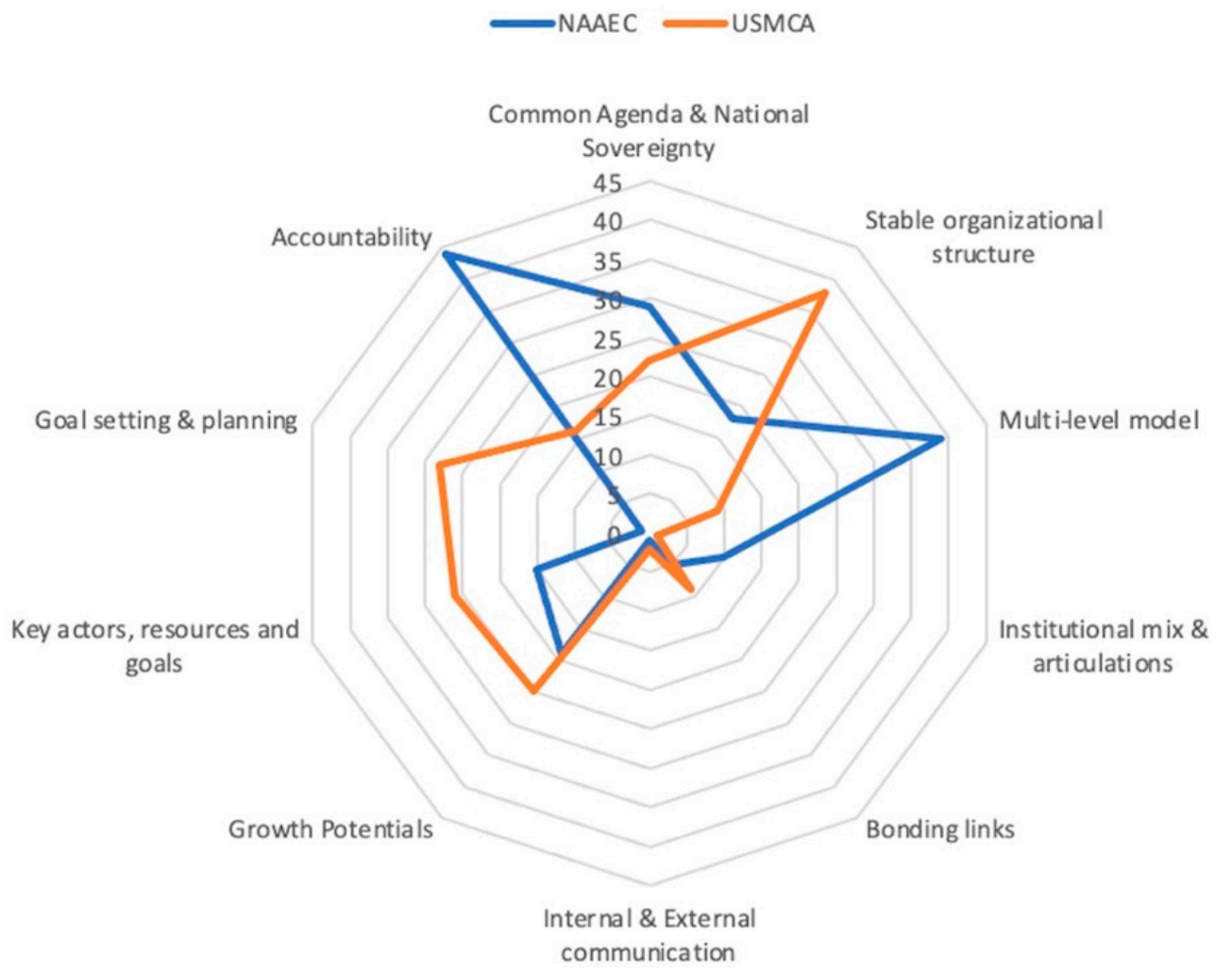

Figure 4. NAAEC vs. USMCA cross-border governance. Source: elaborated by authors.

Basic statistics on the number of times the CBG criteria are addressed (see second column of Table 2) show that six out of the ten CBG criteria appear more than ten times in Chapter 24; however, if the population's median (19) is taken into account the higher half is above 20 times. This value is close to the average (17.6), although the population is highly scattered, as demonstrated by the coefficient of variance of $69 \%$. This means that the CBG criteria are not given the same level of importance. 
According to the median population, the higher half of the criteria in descending order are: stable organizational structure, goal setting and planning, key actors, resources and goals, growth potentials and common agenda and national sovereignty; this last criterion establishes common grounds for the member states' interaction for the construction of a shared view of interventions and outcomes expected from environmental policy. The other four dimensions refer to networking among institutions and stakeholders as a second level of cooperation to achieve the goals set in the common agenda. In addition, representative keywords of the most common terms belong to the legal and management areas.

The lower half of the criteria in descending order are: accountability, bonding links, multi-level model, internal and external communication and institutional mix and articulations. The few occurrences of their related keywords indicate that preponderance is given to national regulations under legal and management realms.

On the other hand, Figure 4 shows the environmental governance at the asymmetric border between Mexico and the U.S. over a 27-year period. From 1994 to 2018, NAAEC stressed the importance of accountability and a multi-level model, in particular based on regulations and procedures, respectively. Growth potential based on resources was of secondary importance. From 2020 onwards, the USMCA places the highest relevance on stable organizational structure on international issues, while (1) growth potentials (on development), (2) key actors, resources, and goals (on resources) and (3) goal setting and planning criteria (on management) are of secondary importance. These three criteria have gained modest attention.

Differences depicted in Figure 4 suggest that NAECC placed a greater emphasis on operational dimensions, seemingly related to policy design and enforcement. Alternatively, the USMCA focusses on the legal design of common grounds while maintaining intact national regulations. Despite the changes observed over the 27-year period, criteria driving "good" cross-border governance were and are not attended to in a balanced manner.

In order to check the above results Chapter 24 was further inspected; one identifies that article 24.2 states that trade contributes to sustainable development in the sense that environmental aspects related to trade are the scope for cooperation; however, article 24.3 declares the independence of the three countries in regard to protection levels and environmental policies, as long as environmental standards or laws do not become a hidden barrier for trade or investment as mentioned in article 24.2.

Additional inspection of Chapter 24 indicates that given articles cover specific environmental issues; for example, article 24.9 refers to the ozone layer, articles 24.10, 24.12 and 24.17-24.21 relate to the marine environment and marine resources, article 24.11 focuses on air quality, 24.15 on biodiversity and 24.22 on conservation. As seen, topics of the greatest management interest are marine, fishing and fisheries, and this is clearly pictured in Figures 2 and 3.

Results so far reveal that the USMCA treaty reinforces national policies and institutions to deal with environmental issues impacting trade and defines a mechanism to resolve controversies among member states. That is, the USMCA treaty does not create an integrated setting of objectives framing common policies; furthermore, to some extent it seems to dismantle the previous institutional framework that aimed to build convergence in the border region, and in a backwards step to national policies there are not transitional spaces nor transferring institutions to foster a coherent construction of environmental initiatives from a territorial perspective.

The only attempt at environmental regional integration identified in the USMCA treaty is the mandate to create the Committee for the Environment (CEC)—this has a monitoring function and should meet every two years unless the very same CEC decides otherwise. This agency hardly seems fit to be an environmental policy leader able to enhance convergence among the member states.

However, given the nature of the USMCA treaty to channel international relations, it should incorporate a territorial angle on each border region including the role of local networks and actors. From a macro perspective, all criteria driving "good" cross-border 
governance seem present in Chapter 24, yet the relevance is placed on dimensions aiming to set a broad institutional and procedural framework to deal with environmental issues among the three countries without any specific territorial reference.

The USMCA agreement sets guidelines for national interaction based on the preeminence of pre-existing national institutions and regulations, such interaction is built on mutual respect of sovereignty rather than on integration. Thus, operation under such circumstances means that the intermediate level of bonding, communication and institutional mix lose centrality.

\section{Conclusions}

The aim when evaluating a governance model is to identify gaps and recommend improvements, bearing in mind the specific characteristics of the territories under study.

In the asymmetric border between Mexico and the U.S., the prevailing environmental CBG model that began in the 1990s came to an end in 2018. It was replaced by a new model defined by the USMCA treaty; however:

- How good is the current environmental cross-border governance adopted at the U.S.Mexico border region?

- What sort of measures should be taken to address the complex and long-term environmental problems in U.S.-Mexico cross-border governance?

To answer these questions the Chapter 24, "Environment", of the USMCA treaty was analyzed to measure how good it is according to the evaluating criteria for governance models of Wong Villanueva et al. [41]. In general terms this exercise looked for the existence of a framework on institutional integration. To complement this first exercise, a comparison was made between the new and previous models.

In relation to the first question, the current environmental governance at the U.S.Mexico border region is not good enough and will not be very efficient in the future if it is not updated. This statement is based on results that indicated that the USMCA treaty does not creates an integrated setting of objectives framing common policies to deal with shared environmental issues. Furthermore, the current model does not seem to integrate lessons learned from the environmental governance model established by NAFTA that operated in the region for over a quarter of a century.

Nowadays, the environmental CBG has created a common legal framework relying on the creation of common institutions that have lost their centrality. This reorientation demands the establishment of a clearer set of common rules and rethinking the operation of existing border organizations such as BECC and NADBank. If these two aspects are not covered, we will not have a sound institutional framework as stated at the beginning of the paper; an efficient institutional framework includes both rules and organizations.

Regarding the second question, results pointed to the need to adopt a more integral environmental governance model with which to face complex and long-term environmental problems in the U.S.-Mexico border region. This need is not recent, as a comparison of the performance of previous and current models showed an imbalance in the ten evaluating criteria. It must be admitted that there are modest advances in the USMCA, in particular on three criteria: (1) goal setting and planning, (2) key actors, resources and goals and (3) growth potential, in current environmental governance. It is important to stress that number (2) highlights that resources are bases for trade in accordance with the treaty provisions.

The results also revealed that the new regulations seem even more focused on trade than those related to NAFTA, that environmental governance falls heavily on national regulations and that other international treaties dealing with environmental commitments are left aside. Comparisons between previous and present environmental governance models at the border region exhibited that the strategy to level asymmetries was by creating institutions to drive convergence through the BECC and NADBank in the past. The new strategy to level asymmetries is a nationally centered strategy. In any case, trade does not seem to be the most powerful promoter of environmentally efficient cooperation. 
The main challenge for cross-border environmental governance at the U.S.-Mexico border region is that environmental problems are still approached in a fragmented way and hence inefficiently; if persisting in such fashion, environmental degradation is likely to expand, facing population growth and presence of climate-change-related events.

Recommendations of this study are first to understand and accept that environmental issues should be approached in an integral way to be effectively resolved; second, that lessons from NAFTA should be reviewed and those found useful should be incorporated into the USMCA; third, strategies to address asymmetries should be drawn up in a resilience and flexible manner, able to survive periods of high and low levels of cooperation brought by changing political climates; and finally, to look for alternative and complementary pathways of integration.

Author Contributions: Conceptualization, G.M.-M.; methodology, G.M.-M.; software, G.M.-M.; validation, G.M.-M. and S.E.M.-P.; formal analysis, G.M.-M. and S.E.M.-P.; investigation, G.M.-M. and S.E.M.-P.; data curation, G.M.-M.; writing—original draft preparation, G.M.-M.; writing-review and editing, S.E.M.-P. and G.M.-M.; visualization, G.M.-M. All authors have read and agreed to the published version of the manuscript.

Funding: This research received no external funding.

Institutional Review Board Statement: Not applicable.

Informed Consent Statement: Not applicable.

Conflicts of Interest: The authors declare no conflict of interest.

\section{References}

1. Comisión Europea. La gobernanza Europea; Un libro Blanco; Comisión Europea: Bruselas, Bélgica, 2001; p. 428.

2. Delreux, T. Regional Governance. In Essential Concepts of Global Environmental Governance; Morin, J.-F., Orsini, A., Eds.; Routledge: London, UK, 2015; p. 252.

3. Kirschke, S.; Borchardt, D.; Newig, J. Mapping Complexity in Environmental Governance: A comparative analysis of 37 priority issues in German water management. Environ. Policy Gov. 2017, 27, 534-559. [CrossRef]

4. Underdal, A. Complexity and challenges of long-term environmental governance. Glob. Environ. Chang. 2010, 20, 386-393. [CrossRef]

5. Patterson, J.J.; Smith, C.; Bellamy, J. Understanding enabling capacities for managing the 'wicked problem' of nonpoint source water pollution in catchments: A conceptual framework. J. Environ. Manag. 2013, 128, 441-452. [CrossRef] [PubMed]

6. Head, B.W. Evidence, Uncertainty, and Wicked Problems in Climate Change Decision Making in Australia. Environ. Plan. C Gov. Policy 2014, 32, 663-679. [CrossRef]

7. Conca, K. The Rise of the Region in Global Environmental Politics. Glob. Environ. Politics 2012, 12, 127-133. [CrossRef]

8. Wingqvist, G.Ö.; Drakenberg, O.; Slunge, D.; Sjöstedt, M.; Ekbom, A. The Role of Governance for Improved Environmental Outcomes. Perspectives for Developing Countries and Countries in Transition; Naturvårdsverket: Stockholm, Sweden, 2012; p. 59.

9. Badenoch, N. Transboundary Environmental Governance. Principles and Practice in Mainland Southeast. Asia; World Resources Institute United States: Washington, DC, USA, 2002; p. 37.

10. Durth, R. European experience in the solution of cross-border environmental problems. Intereconomics 1996, 31, 62-67. [CrossRef]

11. O'Brien, M.; Penna, S. European Policy and the Politics of Environmental Governance. Policy Politics 1997, 25, 185-200. [CrossRef]

12. Macrory, R.; Turner, S. Cross-border Environmental Governance: The EC Law Dimensions. Reg. Fed. Stud. 2002, 12, 59-87. [CrossRef]

13. Wurzel, R.K.; Zito, A.R.; Jordan, A.J. Environmental Governance in Europe: A Comparative Analysis of the Use of New Environmental Policy Instruments; Edward Elgar Publishing: Northampton, MA, USA, 2013.

14. Capello, R.; Caragliu, A.; Fratesi, U. Measuring border effects in European cross-border regions. Reg. Stud. 2018, 52, $986-996$. [CrossRef]

15. Wiering, M.; Verwijmeren, J.; Lulofs, K.; Feld, C. Experiences in Regional Cross Border Co-operation in River Management. Comparing Three Cases at the Dutch-German Border. Water Resour. Manag. 2010, 24, 2647-2672. [CrossRef]

16. Scherer, R.; Zumbusch, K. Limits for successful cross-border governance of environmental (and spatial) development: The Lake Constance Region. Procedia Soc. Behav. Sci. 2011, 14, 101-120. [CrossRef]

17. Munteanu, A.M.; Ehlinger, T.; Golumbeanu, M.; Tofan, L. Network environmental governance in the EU as a framework for trans-boundary sturgeon protection and cross-border sustainable management. J. Environ. Prot. Ecol. 2013, 14, 685-692.

18. Vulevic, A.; Castanho, R.A.; Gómez, J.M.N.; Lausada, S.; Loures, L.; Cabezas, J.; Fernández-Pozo, L. Cross-Border Cooperation and Adaptation to Climate Change in Western Balkans Danube Area. In Governing Territorial Development in the Western Balkans; Springer: Cham, Switzerland, 2021; pp. 289-308. [CrossRef] 
19. Carter, T.R.; Benzie, M.; Campiglio, E.; Carlsen, H.; Fronzek, S.; Hildén, M.; Reyer, C.P.; West, C. A conceptual framework for cross-border impacts of climate change. Glob. Environ. Chang. 2021, 69, 102307. [CrossRef]

20. Hamman, P. (Ed.) Cross-Border Renewable Energy Transitions: Lessons from Europe's Upper Rhine Region; Routledge: London, UK, 2021.

21. Blatter, J. Emerging cross-border regions as a step towards sustainable development? Experiences and considerations from examples in Europe and North America. Int. J. Econ. Dev. 2000, 2, 402-440.

22. Clarke, S.E. Spatial concepts and cross-border governance strategies: Comparing North American and Northern Europe experiences. In Proceedings of the EURA Conference on Urban and Spatial European Policies, Turin, Italy, 18-20 April 2002.

23. Oddone, N.; Vázquez, H.R.; Oro, M.J. Local cross-border paradiplomacy as an environmental governance tool in Mercosur and the European Union: A comparative approach. Civitas-Rev. de Cienc. Sociais 2018, 18, 332-350.

24. Elliott, L. ASEAN and environmental governance: Rethinking networked regionalism in Southeast Asia. Proc. Soc. Behav. Sci. 2011, 14, 61-64. [CrossRef]

25. Miller, M.A.; Middleton, C.; Rigg, J.; Taylor, D. Hybrid Governance of Transboundary Commons: Insights from Southeast Asia. Ann. Am. Assoc. Geogr. 2019, 110, 297-313. [CrossRef]

26. Setyaka, V. Politics of Civil Society Organizations on Environmental Governance in ASEAN. Creating ASEAN Futures 2015: Towards Connected Cross-Border Communities. In Proceedings of the International Indonesian Forum for Asian Studies, Andalas University, Padang, West Sumatra, Indonesia, 28-29 September 2015.

27. Ma, X.; Tao, J. Cross-border environmental governance in the Greater Pearl River Delta (GPRD). Int. J. Environ. Stud. 2010, 67, 127-136. [CrossRef]

28. Li, J.; Shi, X.; Wu, H.; Liu, L. Trade-off between economic development and environmental governance in China: An analysis based on the effect of river chief system. China Econ. Rev. 2019, 60, 101403. [CrossRef]

29. Liu, C.-H.; Sun, Y.; Han, Y. Regional environmental governance of the Yellow Sea and Bohai Sea from the perspective of land and sea coordination: Conference report. Mar. Policy 2021, 127, 104446. [CrossRef]

30. Yijing, C.; Jue, W. Study on the Cooperation Mechanism of Transboundary Water Pollution Control in China from the Perspective of Network Governance. E3S Web Conf. 2019, 136, 06009. [CrossRef]

31. Nam, S. Ecosystem Governance in a Cross-Border Area: Building a Tuman River Transboundary Biosphere Reserve. China Environ. Ser. 2005, 7, 83-88.

32. Yok-shiu, F.L. Tackling cross-border environmental problems in Hong Kong: Initial responses and institutional constraints. China Q. 2002, 172, 986-1009.

33. Marshall, G.R.; Connell, D.; Taylor, B.M. Australia's Murray-Darling Basin: A Century of Polycentric Experiments in Cross-Border Integration of Water Resources Management. Int. J. Water Gov. 2013, 1, 197-218. [CrossRef]

34. Kimani, N. A Collaborative Approach to Environmental Governance in East Africa. J. Environ. Law 2009, 22, 27-57. [CrossRef]

35. Lin, T.; Catacutan, D.; Malesu, M. Multi-Stakeholder Platforms for Cross-Border Biodiversity Conservation and Land-Scape Governance in East Africa: Perspectives and Outlook; World Agroforesty (ICRAF): Nairobi, Kenia, 2021.

36. Godsäter, A. Regional Environmental Governance in the Lake Victoria Region: The Role of Civil Society. Afr. Stud. 2013, 72, 64-85. [CrossRef]

37. Boillat, S.; Scarpa, F.M.; Robson, J.P.; Gasparri, N.I.; Aide, T.M.; Aguiar, A.P.D.; Anderson, L.O.; Batistella, M.; Fonseca, M.; Futemma, C.; et al. Land system science in Latin America: Challenges and perspectives. Curr. Opin. Environ. Sustain. 2017, 26-27, 37-46. [CrossRef]

38. Duffy, R. The politics of global environmental governance: The powers and limitations of transfrontier conservation areas in Central America. Rev. Int. Stud. 2005, 31, 307-323. [CrossRef]

39. Kirkpatrick, A.B. Transboundary Environmental Governance Across the World's Longest Border. Glob. Environ. Politic 2019, 19, 141-143. [CrossRef]

40. Laine, J. Border Paradox: Striking a Balance between Access and Control in Asymmetrical Border Settings. Eurasia Bor. Rev. 2012, 3, 51-79.

41. Wong Villanueva, J.L.; Kidokoro, T.; Seta, F. Cross-Border Integration, Cooperation and Governance: A Systems Approach for Evaluating "Good" Governance in Cross-Border Regions. J. Borderl. Stud. 2021, 1-24. [CrossRef]

42. United States International Trade Commission (USITC). The Impact of Increased United States-Mexico Trade on Southwest Border Development; United States International Trade Commission (USITC): Washington, DC, USA, 1986.

43. Martinez, O. Borderlands Entering a New Stage. Mex. Policy News 1992, 8, 22.

44. Lara, F. Networking on the border. The Realities on Communication among Border entities. In Building a Strong Region Through Effective Communication. Seizing Opportunities in the California-Baja California Region; San Diego Association of Governments (SANDAG): San Diego, CA, USA, 2000.

45. Peña, S. Cross-border planning at the U.S.-Mexico border: An institutional approach. J. Borderl. Stud. 2007, 22, 1-18. [CrossRef]

46. Ostrom, E. Governing the Commons; Cambridge University Press: Cambridge, UK, 1990.

47. Alfie Cohen, M.; Flores Jauregui, O. Las agencias ambientales binacionales de México y Estados Unidos: Balance y perspectiva a dieciséis años de su creación. Norteamérica 2010, 5, 129-172.

48. Hufbauer, G.; Jones, R. North American Convergence: An American Perspective; SICE, Foreign Trade Information System: Miami, FL, USA, 2000. 
49. Mumme, S.P.; Collins, K. The La Paz Agreement 30 Years On. J. Environ. Dev. 2014, 23, 303-330. [CrossRef]

50. Mumme, S. Reflections on Public Participation in Environmental Protection Policy on the U.S.-Mexico Border. Retos Ambientales y Desarrollo Urbano en la Frontera Mexico-Estados Unidos; DeparTamento de Estudios Urbanos y Medio Ambiente, Eds.; Colegio de la Frontera Norte: Tijuana, Mexico, 2009.

51. Nam Kwon, M.; Andrés-Rosales, R.; Quintana Romero, L. Crecimiento económico y la contaminación medioambiental en las ciudades mexicanas. J. Iber. Lat. Am. Res. 2016, 22, 31-44.

52. Zito, A.; Aspinwall, M. Green Regions? Comparing Civil Society Activism in NAFTA and the European Union. Perf. Latinoam. 2016, 24, 47.

53. Gallagher, K.P. El TLCAN y el Medio Ambiente: Lecciones de México y Más Allá. In El Futuro de la Politica de Comercio en America del Norte: Lecciones del TLCAN; Pardee Center Task Force Report; Gallagher, K.P., Peters, E.D., Wise, T.A., Eds.; Universidad Autónoma de Zacatecas, Doctorado en Estudios de Desarrollo: Zacatecas, Mexico; Tufts University, Global Development and Environment Institute: Somerville, MA, USA; Boston University Frederick, S. Pardee Center: Boston, MA, USA; Universidad Nacional Autónoma de México, Centro de Estudios China-México: Mexico City, Mexico; Miguel Ángel Porrúa: Mexico City, Mexico, 2011.

54. Sanchez Rodriguez, R.A.; Mumme, S.P. Protecting the Environment? In Mexico and the United States: The Politics of Partnership, 1st ed.; Smith, P., Seeley, A., Eds.; Lynne-Reinner Press: Boulder, CO, USA, 2013; pp. 139-159.

55. Malkawi, B.H.; Kazmi, S. Dissecting and Unpacking the USMCA Environmental Provisions: Game-Changer for Green Governance? JURIST: Pittsburgh, PA, USA, 2020.

56. Benoit, K.; Watanabe, K.; Wang, H.; Nulty, P.; Obeng, A.; Müller, S.; Matsuo, A. quanteda: An R package for the quantitative analysis of textual data. J. Open Source Softw. 2018, 3, 774. [CrossRef] 